\title{
ARTICLE \\ Novel therapies in the management of food allergy: Oral immunotherapy and anti-IgE
}

\author{
C L Gray, E Goddard, S Karabus, M Kriel, A C Lang, A I Manjra, S M Risenga, A J Terblanche, D A van der Spuy, M E Levin, \\ for the South African Food Allergy Working Group (SAFAWG)
}

All authors' degrees, affiliations and conflict of interest statements can be found online at http://dx.doi.org/10.7196/SAMJ.9201

Corresponding author: C Gray (claudiagray.paediatrics@gmail.com)

The process of oral immunotherapy (OIT) consists of a series of dose escalations with the immediate goal of inducing desensitisation and ultimately achieving a state of tolerance.

Owing to the limitations of OIT, including side-effects and lack of proven efficacy in long-term tolerance induction, it is not yet recommended in routine clinical practice and should be restricted to the research setting.

Studies using anti-immunoglobulin E (IgE) antibody in food allergy management are limited, but show promising results. The possible applications are for increasing the sensitivity threshold to certain foods such as peanut, and also for use in combination with OIT to enhance safety and rapidity of the OIT process; however, anti-IgE is not yet licensed for use in food allergy.

S Afr Med J 2015;105(1):74. DOI:10.7196/SAMJ.9105

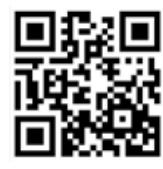

\section{Oral immunotherapy}

Oral immunotherapy (OIT) is the only strategy that aims to achieve a 'cure' for the food allergic patient. ${ }^{[1]}$ In most OIT protocols, small amounts of allergen are administered to patients in gradually increasing amounts, with the immediate goal of inducing desensitisation, and ultimately of achieving a state of tolerance. ${ }^{[2-4]}$ With desensitisation, the treated patient manifests a decreased response to the ingested food allergens, but must continue to take daily food doses to maintain non-reactivity. In a state of tolerance, patients with food allergy may safely consume food without following a daily oral food regimen to maintain clinical non-reactivity.

OIT is a lengthy process (months - years) and consists of a series of dose escalations (usually in a controlled setting), with intervening maintenance periods (usually daily doses at home). ${ }^{[5]}$

The safety of OIT is problematic, with allergic reactions, including mild and severe reactions, developing in most patients. Long-term tolerance has not yet been adequately assessed. ${ }^{[6]}$

Owing to the many limitations of OIT, it is not yet recommended in routine clinical practice and should be restricted to the research setting.

\section{Anti-IgE antibody}

Currently, the most widely used anti-immunoglobulin E (IgE) antibody is omalizumab. ${ }^{[6]}$ It is approved for treating aeroallergensensitised children and adults ( $\geq 12$ years of age in the USA, $\geq 6$ years in Europe) with moderate-to-severe persistent asthma inadequately controlled with inhaled corticosteroids.

Studies using anti-IgE antibody in food allergy management are limited, but show promising results. Possible applications are for increasing the threshold of sensitivity to certain foods such as peanut, ${ }^{[7,8]}$ and combined with OIT to enhance safety and rapidity of the OIT process. ${ }^{[9,10]}$ Anti-IgE is however not yet licensed for use in food allergy.

\section{References}

1. Nowak-Wegrzyn A, Muraro A. Food allergy therapy: Is a cure within reach? Pediatr Clin N Am 2011;58:511-530. [http://dx.doi.org/10.1016/j.pcl.2011.02.010]

2. Scurlock AM, Vickery BP, Hourihane JO, et al. Pediatric food allergy and mucosal tolerance. Mucosal Immunol 2010;3:345-354. [http://dx.doi.org/10.1038/mi.2010.21]

3. Scurlock AM, Burks AW, Jones SM. Oral immunotherapy for food allergy. Curr Allergy Asthma Rep 2009;9:186-193. [http://dx.doi.org/10.1007/s11882-009-0028-z]

2009;9:186-193. [http://dx.doi.org/10.1007/s1 1882-009-0028-z]
4. Nowak-Wegrzyn A, Sampson HA. Future therapies for food allergies. J Allergy Clin Immunol 40wak-Wegrzyn A, Sampson HA. Future therapies for food a

5. Nadeau KC, Kohli A, Iyengar S. Oral immunotherapy and anti-IgE antibody- adjunctive treatment for 5. Nadeau KC, Kohli A, Iyengar S. Oral immunotherapy and anti-IgE antibody- adjunctive treatment for
food allergy. Immunol Allergy Clin N Am 2012;32:111-133. [http://dx.doi.org/10.1016/j.iac.2011.11.004] 6. Humbert M, Beasley R, Ayres J, et al. Benefits of omalizumab as add-on therapy in patients with severe persistent asthma who are inadequately controlled despite best available therapy (GINA 2002 step 4 treatment): INNOVATE. Allergy 2005;60:309-316. [http://dx.doi.org/10.1111/j.1398-9995.2004.00772.]

7. Leung DY, Sampson HA, Yunginger JW, et al. Effect of anti-IgE therapy in patients with peanut allergy. N Engl J Med 2008;348(11):986-993. [http://dx.doi.org/10.1056/NEJMoa022613]

8. Sampson HA, Leung DY, Burks AW, et al. A phase II, randomized, double-blind, parallel-group, placebo-controlled oral food challenge trial of Xolair (omalizumab) in peanut allergy. J Allergy Clin Immunol 2011;127(5):1309.e1-e10. [http://dx.doi.org/10.1016/j.jaci.2006.11.440]

9. Nadeau KC, Schneider LC, Hoyte L, et al. Rapid oral desensitization in combination with omalizumab therapy in patients with cow's milk allergy. J Allergy Clin Immunol 2011;127(6):1622-1624. [http:// dx.doi.org/10.1016/j.jaci.2013.09.046]

10. Schneider LC, Rachid R, Lebovidge J, Blood E, Mittal M, Umetsu DT. A pilot study of omalizumab to facilitate rapid oral desensitization in high-risk peanut-allergic patients. J Allergy Clin Immunol 2013;132(6):1368-1374. [http://dx.doi.org/10.1016/j.jaci.2013.09.046] 